\author{
유산균주의 종류에 따른 쌀 첨가 요구르트의 발효 특성 \\ 배형철* . 백승희** . 남명수* \\ 충남대학교 농업생명과학대학 동물자원학부*, 천안연암대학 외식산업학과**

\section{Fermentation Properties of Rice Added Yogurt Made with Various Lactic Acid Bacteria} \\ H. C. Bae*, S. H. Paik** and M. S. Nam* \\ Division of Animal Science \& Resources, College of Agriculture \& Life Sciences, Chungnam \\ National University, Daejeon 305-764, KOREA*, \\ Department of Food Service Industry, Cheonan Yonam College, KOREA*
}

\begin{abstract}
The objective of this experiment was to select the best strain of lactic acid bacteria for the manufacture of new type of yogurt with rice powders. Changes in $\mathrm{pH}$, titratable acidity, viable cell counts, viscosity, organic acid contents, carbohydrates during fermentation were monitored and sensory evaluation were examined. The yogurt added with $4 \%$ rice or skim milk powders and $L$. salivarius ssp. salivarius culture did not reach $\mathrm{pH}$ 4.5 , because the production of acids in this media for the culture was weak. The yogurt added with $4 \%$ rice or skim milk powder with $L$. casei, the $\mathrm{pH}$ was low and the titratable acidity was high, and therefore the quality of yogurt after 8 hours from fermentation was not high. The yogurt added with $4 \%$ rice or skim milk powders with a mixed culture of B. longum, L. acidophilus, Streptococcus salivarius ssp. thermophilus was considered best for achieving $\mathrm{pH} 4.5$ and titratable acidity of $1.0 \%$ from 8 to 14 hours. The yogurt with a mixed culture had more acetic acid. Galactose was accumulated when $L$. salivarius ssp. salivarius or the mixed culture were used for fermenting yogurt. In sensory evaluation, the yogurt with the mixed culture received high overall sensory score. From these results, a mixed culture of B. longum, L. acidophilus, Streptococcus salivarius ssp. thermophilus was identified as the best for the manufacture of yogurt added with rice powder.
\end{abstract}

(Key words : Rice powder, Lactic acid bacteria, Viable cell counts, Viscosity, Organic acid, Sensory evaluation)

$$
\mathrm{I} \text { 서 론 }
$$

요구르트의 유고형분 함량을 높이기 위한 방 법으로는 예전에는 우유를 끓여 농축시키는 방 법이 사용되어졌고 그 후 진공농축방법이나 막 여과 등으로 우유를 농축하는 방법이 사용되고 있다(Tamine과 Robinson, 1985). 그러나 탈지분 유, 전지분유, 버터밀크 분말, 유청 분말, casein 분말 등을 첨가하여 고형분 함량을 증가시키는 방법이 가장 일반적인 방법이다. 요구르트의
점도를 증가시키기 위한 방법은 안정제를 첨가 하는 것인데 일반적으로 낮은 농도의 젤라틴, 펙틴, 한천 등이 사용되고 있다. 이들 안정제를 적절하게 사용하면 요구르트의 점도가 증가하 고 유청의 분리가 억제되어 첨가하지 않은 제 품보다 관능성을 크게 개선시킬 수 있다(안 등, 1988). 그 밖에 요구르트의 점도 증가는 김과 고(1993)에 의하면 곡류의 첨가군이 요구르트의 점도가 대체적으로 유의성있게 높았다고 보고 하였으며 이는 곡류에 함유된 고형분, 특히 전

\footnotetext{
Corresponding author : M. S. Nam, Division of Animal Science \& Resources, College of Agriculture \& Life Sciences, Chungnam National University, Daejeon 305-764, KOREA, Tel : 042-821-5782, E-mail : namsoo@cnu.ac.kr
} 
분에 의하여 점도가 높아진 것으로 보고하였 다. 그러므로 요구르트의 점도 증가를 위한 하 나의 방법으로 쌀 분말 첨가를 고려해 볼 수 있다.

젖산균의 종류를 달리하여 제조한 요구르트 의 보고는 Shin(1989)은 멥쌀에 a-amylase를 작용시켜 액화시킨 후 이 액에 L. delbrueckii ssp. bulgaricus와 Streptococcus salivarius ssp. thermophilus, L. plantarum 을 단독으로 또는 혼 합하여 접종한 후 발효시켰고, 목 등(1991)은 호화시킨 쌀을 당화시킨 후 L. delbrueckii ssp. bulgaricus와 Streptococcus salivarius ssp. thermophilus, L. plantarum을 단독으로 또는 Streptococcus salivarius ssp. thermophilus와 혼 합 배양하였고, 홍과 고(1991)는 우유에 탈지 분유 또는 4종의 쌀(멥쌀, 찹쌀, 현미, 통일 벼)을 각각 $2 \%(\mathrm{w} / \mathrm{v})$ 첨가하여 4 종의 젖산균 (Lactobacillus 3종, Leuconostoc 1종)을 접종하여 발효시켰다. 또한 김과 고(1993)는 우유와 쌀, 보리, 밀, 옥수수를 이용한 요구르트를 제조하 였는데 접종된 3종의 젖산균 가운데 산 생성이 우수한 것은 L. acidophilus였으며 L. casei와 L. delbrueckii의 산 생성은 저조하였다. 이 등 (1988)은 쌀 - 대두분 혼합액을 기질로 하는 젖 산균음료 발효에 관한 연구에서 Bacillus와 효 모의 혼합 배양을 이용한 고체 상태의 예비 발 효와 extruder를 이용한 압출 조리 전처리가 젖 산균(L. plantarum과 Leuconostoc mesenteroides의 혼합 배양)의 생육에 미치는 효과를 검토하였다. $\mathrm{Yu}$ 와 Lee(1982)는 보리당화액(보리를 맥아 조효 소액으로 당화한 것)과 탈지유의 단독 및 혼합 배지에 배양 적성이 좋은 젖산 균주들은 $L$. acidophilus, L. aplantarum, L. lactis, L. delbrueckii ssp. bulgaricus + Streptococcus salivarius ssp. thermophilus 등 이었다고 보고하였다.

본 연구는 백 등(2004)이 얻은 결과에서 $L$. delbrueckii ssp. bulgaricus와 Streptococcus salivarius ssp. thermophilus 혼합균주를 사용하 여 제조한 요구르트의 경우 최적인 조건을 기 초로 하여 탈지유에 $4 \%$ 쌀 분말을 첨가하여 단독 균주인 L. casei와 B. longum, L. acidophilus, Streptococcus salivarius ssp. thermophilus의 혼합
균주 및 한국인의 분변에서 분리한 L. salivarius ssp. salivarius(배, 2002) 균주를 사용하여 요구 르트를 제조한 후 젖산균의 종류에 따른 발효 특성을 비교해 보았다.

\section{재료 및 방법}

\section{1. 요구르트의 제조}

(1) 공시균주

요구르트 제조에 사용한 공시균주는 $10 \%$ 의 탈지분유 배지(Difco, USA)를 $121^{\circ} \mathrm{C}$ 에서 15 분 간 열처리한 후 Nocks 사(Japan) 제품인 $L$. casei와 혼합 균주인 B. longum, L. acidiphilus, Streptococcus salivarius ssp. thermophilus 및 한 국인의 분변으로부터 분리한 L. salivarius ssp. salivarius(배, 2002)를 모 배양한 다음 $2 \%$ 배양 액을 접종하여 24시간 동안 1차 배양하였으며 이것을 반복하여 2회 계대 배양한 것을 스타터 로 사용하였다.

\section{(2) 원료유}

충남대학교 부속 동물사육장의 홀스타인종으 로부터 신선한 원유를 크림분리기(Armfield Technical Education Co., Ltd., England)를 사용 하여 유지방을 분리한 후 탈지유를 요구르트 의 원료유로 사용하였다.

\section{(3) 쌀 분말}

쌀 분말은 충남 당진군 대호지면 대호가람농 장에서 생산한 유기농 쌀을 구입하여 증류수에 24시간 상온에 정치한 후 균질기(KMF-300; Daewoo Elec., Korea)로 분쇄하고 $50^{\circ} \mathrm{C}$ 에서 건 조한 후 표준망체 $42 \mathrm{mesh}$ 를 통과시킨 것을 쌀 분말 첨가제로 사용하였다.

(4) 요구르트의 제조방법

쌀 요구르트의 제조 시 배합비율은 백 등 (2004)에서 최적의 기질 농도로 선정된 $4 \%$ 의 쌀 분말과 탈지분유를 동량으로 첨가한 후 water bath를 사용하여 $92^{\circ} \mathrm{C}$ 에서 10 분간 가열, 살균하였다. 살균 후 $40^{\circ} \mathrm{C}$ 에서 스타터를 $2 \%$ 접 
종하고 $42^{\circ} \mathrm{C}$ 에서 14 시간 배양하면서 2 시간 간 격으로 시료를 채취하여 산도, $\mathrm{pH}$, 젖산균 수 를 측정하였으며, 발효유의 산도가 $1.0 \%$ 에 도 달하였을 때의 시료를 채취하여 점도, 관능검 사, 유기산 및 유당의 함량을 측정하였다.

\section{2. 요구르트의 분석}

(1) 산 생성량 측정

요구르트의 배양 시간에 따른 산 생성량은 이(1983)의 방법에 따라 측정하였으며, $\mathrm{pH}$ 는 $\mathrm{pH}$ meter(420A; Orion Research Inc., USA)를 사 용하여 측정하였다.

(2) 젖산균 수 측정

멸균수에 십진희석하여 젖산균 배지(BCP plate count agar, Eiken Chemical Co. Ltd., Japan)에 접 종한 후 표준 평판법으로 $42^{\circ} \mathrm{C}$ 에서 48 시간 배양 한 후에 나타난 colony 수를 측정하였다(이, 1983).

\section{(3) 점도}

요구르트의 산도가 $1.0 \%$ 에 도달하였을 때 $5{ }^{\circ} \mathrm{C}$ 냉장고에서 24시간 냉각한 후 Brookfield viscometer(BM type; Tokimec Inc., Japan)의 rotor No. 2를 사용하여 $12 \mathrm{rpm}$ 에서 측정하였다.

(4) 유기산

요구르트의 유기산 분석은 Saidi와 Warthesen (1989)의 방법에 따라 분석하였다. 각각의 시료 를 $5 \mathrm{~g}$ 을 채취하여 $12 \%$ TCA 용액을 $1 \mathrm{~m} \ell$ 첨가 하고 $5,000 \mathrm{~g}$ 에서 5 분간 원심분리 하였다. 분리 된 상등액을 채취하여 $0.2 \mu \mathrm{m}$ membrane filter (Sartorius AG, Germany)를 사용하여 여과한 후 HPLC system을 사용하여 유기산 농도를 분석 하였다. 시험에 사용된 유기산의 표준물질은 Sigma-Aldrich Co.(U.S.A.)에서 구입하여 분석에 사용하였다.

(5) 탄수화물

요구르트의 탄수화물 분석은 Jeon 등(1984)의 방법에 따라 분석하였다. 각각의 시료의 전처 리는 유기산 시험방법과 동일하게 하였으며,
HPLC system을 사용하여 탄수화물 농도를 분 석하였다. Detector는 Refractive Index Detector (Waters Associates, U.S.A.)를 사용하였다. column은 SUPELCOGEL C-610H을 사용하였고, col$\mathrm{umn}$ 의 온도는 $40^{\circ} \mathrm{C}$ 를 유지하였고, 이동상은 HPLC용 Water(TEDIA Company Inc., U.S.A.)를 사용하여 $1.0 \mathrm{ml} / \mathrm{min}$ 의 유속으로 10 분간 분석하 였다. 분석프로그램은 Autochro-WIN 2.0 plus를 사용하여 정량분석 하였다. 시험에 사용된 표 준물질은 Sigma-Aldrich Co.에서 구입하여 분석 에 사용하였다.

(6) 관능검사

요구르트의 산도가 $1.0 \%$ 에 도달하였을 때 $5^{\circ} \mathrm{C}$ 냉장고에서 24 시간 냉각한 후 30 명의 검사원 으로 색, 풍미, 맛의 조화, 조직감 및 전체적인 기호도를 5점 scoring test로 평가하였다. 이때 평가 요령은 각각의 평가항목에 대하여 " 1 : 대 단히 나쁘다, $2:$ 나쁘다, $3:$ 보통이다, $4:$ 좋다, 5 : 대단히 좋다” 로 표시하도록 하였다.

\section{(7) 통계처리}

SPSS 10.0 을 사용하여 쌀 분말과 탈지분유의 첨가량 및 젖산 균주의 종류에 따른 점도 및 관능적인 특성을 비교하였다. 시료간의 유의적 인 차이는 Duncan's multiple range test로 유의수 준 $5 \%(\mathrm{p}<0.05)$ 에서 검증하였다.

\section{III 결과 및 고찰}

\section{1. $\mathrm{pH}$}

젖산 균주를 달리하여 제조한 요구르트의 $\mathrm{pH}$ 변화는 Table 1과 같다. Table 1에 나타난 바와 같이 L. salivarius ssp. salivarius, L. casei 및 $B$. longum, L. acidophilus, Streptococcus salivarius ssp. thermophilus의 혼합 균주로 제조한 요구르 트의 경우 배양 직후 $\mathrm{pH}$ 가 $6.2 \sim 6.3$ 정도를 나타내어 백 등(2004)의 결과는 쌀 분말과 탈지 분유 $4 \%$ 에 상업용 혼합 균주인 L. delbrueckii ssp. bulgaricus와 Streptococcus salivarius ssp. thermophilus를 접종한 요구르트의 경우 배양 
Table 1. Changes of $\mathrm{pH}$ during fermentation by various lactic acid bacteria

\begin{tabular}{lcccccccc}
\hline \multirow{2}{*}{ Sample } & \multicolumn{7}{c}{ Incubation Time(hrs) } \\
\cline { 2 - 9 } & 0 & 2 & 4 & 6 & 8 & 10 & 12 & 14 \\
\hline \hline RP A & 6.34 & 6.14 & 5.97 & 5.81 & 5.68 & 5.66 & 5.56 & 5.55 \\
RP B & 6.26 & 5.94 & 5.47 & 4.75 & 4.07 & 3.81 & 3.75 & 3.81 \\
RP C & 6.28 & 5.63 & 4.97 & 4.60 & 4.40 & 4.33 & 4.29 & 4.27 \\
SMP A & 6.29 & 6.17 & 6.07 & 5.99 & 5.91 & 5.91 & 5.85 & 5.84 \\
SMP B & 6.22 & 5.93 & 5.47 & 4.79 & 4.18 & 4.18 & 3.73 & 3.79 \\
SMP C & 6.32 & 5.76 & 5.19 & 4.86 & 4.66 & 4.66 & 4.49 & 4.49 \\
\hline
\end{tabular}

RP : $4 \%$ rice powder, SMP : $4 \%$ skim milk powder.

A : L. salivarius ssp. salivarius.

B : L. casei YA-70.

C : mixed culture(B. longum, L. acidophilus and Streptococcus salivarius ssp. thermophilus).

직후의 $\mathrm{pH}$ 가 6.83, 6.80 이었는데 이보다 $\mathrm{pH}$ 가 낮게 나타났다. 쌀 분말을 첨가한 시료와 탈지 분유를 첨가한 시료 모두 L. salivarius ssp. salivarius로 제조한 요구르트의 경우 $\mathrm{pH}$ 가 가장 완만하게 감소하여 배양 14 시간째까지 적정 $\mathrm{pH}$ 인 4.5에 도달하지 못하였다. L. salivarius ssp. salivarius로 제조한 요구르트 중에서는 쌀 분말을 첨가한 시료가 탈지분유를 첨가한 시료 보다 $\mathrm{pH}$ 가 낮았다.

L. casei로 제조한 요구르트는 쌀 분말을 첨 가한 시료와 탈지분유를 첨가한 시료 모두 $\mathrm{pH}$ 가 급격하게 감소하여 배양 6시간 이후에 $\mathrm{pH}$ 가 4.5 이하로 감소하였으며 배양 14 시간에는 탈지분유를 첨가한 시료의 $\mathrm{pH}$ 가 모든 시료 중 에서 가장 낮았다. B. longum, L. acidophilus, Streptococcus salivarius ssp. thermophilus의 혼합 균주로 제조한 요구르트의 경우 쌀 분말을 첨 가한 시료가 탈지분유를 첨가한 시료보다 $\mathrm{pH}$ 의 변화가 비교적 크게 나타났다. 쌀 분말을 첨가한 시료는 배양 6시간 이후에 적정 $\mathrm{pH}$ 에 도달하였으나 탈지분유를 첨가한 시료는 배양 12 시간째에 적정 $\mathrm{pH}$ 인 4.5에 도달하여 쌀 분말 을 첨가한 시료가 2 배 정도 빠르게 발효가 진 행되었다. 배양 시간에 따른 $\mathrm{pH}$ 로 젖산균주간 의 특성을 비교해보면 L. salivarius ssp. salivarius는 첨가물의 종류에 관계없이 산 생성 의 속도가 가장 느리고 L. casei가 가장 빨랐는 데 특히 탈지분유를 첨가했을 경우이며 $B$. longum, L. acidophilus, Streptococcus salivarius ssp. thermophilus의 혼합 균주에 쌀 분말을 첨 가한 시료의 산 생성이 빠른 것을 알 수 있었다.

\section{2. 산도}

쌀 분말과 탈지분유를 각 $4 \%$ 씩 첨가한 요구 르트 제조 시 젖산균주를 달리한 요구르트의 산도변화는 Table 2 와 같다. 배양 직후의 산 도는 쌀 분말과 탈지분유를 첨가한 시료 모 두 젖산균주에 관계없이 백 등(2004)의 결과 보다 높았으나 배양시간이 경과함에 따라 $L$. salivarius ssp. salivarius로 제조한 요구르트의 경우 쌀 분말과 탈지분유를 첨가한 시료 모두 산도가 완만하게 증가하여 배양 14 시간까지 적 정 산도에 도달하지 못하였는데 이러한 변화는 $\mathrm{pH}$ 의 변화와 일치하였다. L. casei로 제조한 요 구르트의 경우에는 L. salivarius ssp. salivarius 로 제조한 요구르트와 반대로 쌀 분말과 탈지 분유를 첨가한 시료 모두 산도가 급격하게 증 가하기 시작하였다. 쌀 분말을 첨가한 시료는 배양 6시간 이후에, 탈지분유를 첨가한 시료 는 4시간 이후에 적정 산도인 $1.0 \%$ 에 도달하 였고 그 이후에도 산도가 지속적으로 증가하 였는데 탈지분유를 첨가한 시료의 산도가 가장 높았다. B. longum, L. acidophilus, Streptococcus salivarius ssp. thermophilus의 혼합 균주로 제조 한 요구르트 중 쌀 분말을 첨가한 시료는 배양 
Table 2. Changes of titratable acidity during fermentation by various lactic acid bacteria (unit: \%)

\begin{tabular}{lcccccccc}
\hline \multirow{2}{*}{ Sample } & \multicolumn{7}{c}{ Incubation Time(hrs) } \\
\cline { 2 - 9 } & 0 & 2 & 4 & 6 & 8 & 10 & 12 & 14 \\
\hline \hline RP A & 0.39 & 0.34 & 0.38 & 0.42 & 0.46 & 0.52 & 0.58 & 0.58 \\
RP B & 0.42 & 0.52 & 0.80 & 1.02 & 1.13 & 1.27 & 1.39 & 1.43 \\
RP C & 0.39 & 0.47 & 0.75 & 0.92 & 1.12 & 1.39 & 1.55 & 1.67 \\
SMP A & 0.40 & 0.41 & 0.50 & 0.52 & 0.52 & 0.53 & 0.58 & 0.60 \\
SMP B & 0.48 & 0.47 & 0.60 & 0.95 & 1.35 & 1.71 & 2.05 & 2.05 \\
SMP C & 0.39 & 0.41 & 0.55 & 0.78 & 1.01 & 1.10 & 1.20 & 1.21 \\
\hline
\end{tabular}

RP : $4 \%$ rice powder, SMP : $4 \%$ skim milk powder.

A : L. salivarius ssp. salivarius.

B : L. casei YA-70.

C : mixed culture(B. longum, L. acidophilus and Streptococcus salivarius ssp. thermophilus).

6시간 이후에 적정 산도인 $1.0 \%$ 에 도달하였다. 탈지분유를 첨가한 시료는 8 시간 배양에 적정 산도에 도달하였으며 그 이후는 산도가 서서히 증가하여 요구르트의 품질 유지가 비교적 좋을 것으로 생각된다.

\section{3. 젖산균 수}

쌀 분말과 탈지분유를 각 $4 \%$ 씩 첨가한 요구 르트 제조 시 젖산균주를 달리한 요구르트의 젖산균 수는 Table 3과 같다. Table 3에 나타난 바와 같이 L. salivarius ssp. salivarius로 제조한 요구르트 중 쌀 분말을 첨가한 시료는 배양 직
후부터 4시간까지는 젖산균의 수가 급격하게 증가하였으나 그 후 다시 감소하였고 10 시간째 에 증가하기 시작하였다. 탈지분유를 첨가한 시료는 배양 4 시간까지 젖산균의 수가 증가하 였으나 그 이후 2 시간 간격으로 증가와 감소를 반복하다가 12 시간 이후부터 다시 증가하기 시 작하였다.

L. casei로 제조한 요구르트 중 쌀 분말을 첨 가한 시료는 배양 10 시간까지 젖산균의 수가 증가하다가 12 시간에 잠시 감소하였으나 그 이 후에 다시 증가하였다. 탈지분유를 첨가한 시 료는 배양 8시간까지 젖산균의 수가 증가하다 가 쌀 분말을 첨가한 시료와 같은 양상을 보였

Table 3. Changes of viable cell count during fermentation by various lactic acid bacteria

(unit : cfu/m $\ell$ )

\begin{tabular}{lcccccccc}
\hline \multirow{2}{*}{ Sample } & \multicolumn{7}{c}{ Incubation Time(hrs) } \\
\cline { 2 - 8 } & 0 & 2 & 4 & 6 & 8 & 10 & 12 & 14 \\
\hline \hline RP A & $7.8 \times 10^{6}$ & $1.4 \times 10^{7}$ & $1.2 \times 10^{8}$ & $1.2 \times 10^{8}$ & $1.0 \times 10^{7}$ & $9.6 \times 10^{7}$ & $9.6 \times 10^{7}$ & $2.3 \times 10^{8}$ \\
RP B & $8.6 \times 10^{6}$ & $2.7 \times 10^{7}$ & $5.2 \times 10^{7}$ & $6.7 \times 10^{7}$ & $1.2 \times 10^{8}$ & $1.7 \times 10^{8}$ & $1.2 \times 10^{8}$ & $1.9 \times 10^{8}$ \\
RP C & $4.3 \times 10^{6}$ & $4.3 \times 10^{7}$ & $7.9 \times 10^{7}$ & $8.1 \times 10^{7}$ & $8.7 \times 10^{7}$ & $7.2 \times 10^{7}$ & $6.6 \times 10^{7}$ & $1.5 \times 10^{8}$ \\
SMP A & $1.6 \times 10^{6}$ & $3.0 \times 10^{7}$ & $1.1 \times 10^{8}$ & $8.1 \times 10^{8}$ & $1.2 \times 10^{8}$ & $6.9 \times 10^{7}$ & $1.0 \times 10^{8}$ & $2.5 \times 10^{8}$ \\
SMP B & $1.2 \times 10^{6}$ & $3.6 \times 10^{7}$ & $9.6 \times 10^{7}$ & $1.2 \times 10^{8}$ & $3.1 \times 10^{8}$ & $1.8 \times 10^{8}$ & $1.6 \times 10^{8}$ & $3.5 \times 10^{8}$ \\
SMP C & $5.3 \times 10^{6}$ & $6.9 \times 10^{7}$ & $1.0 \times 10^{8}$ & $9.6 \times 10^{8}$ & $1.1 \times 10^{8}$ & $1.1 \times 10^{8}$ & $1.2 \times 10^{8}$ & $4.7 \times 10^{8}$ \\
\hline
\end{tabular}

RP : $4 \%$ rice powder, SMP : $4 \%$ skim milk powder.

A : L. salivarius ssp. salivarius.

B : L. casei YA-70.

C : mixed culture(B. longum, L. acidophilus and Streptococcus salivarius ssp. thermophilus). 
는데 이러한 현상은 B. longum, L. acidophilus, Streptococcus salivarius ssp. thermophilus의 혼 합 균주로 제조한 요구르트 중 쌀 분말을 첨가한 시료에서도 동일하게 나타났다. B. longum, L. acidophilus, Streptococcus salivarius ssp. thermophilus 의 혼합 균주로 제조한 요구르트 중 탈지분유 를 첨가한 시료는 배양 4 시간까지 1 차로 젖산 균의 수가 증가하였으나 잠시 감소하였다가 8 시간 이후부터 증가하기 시작하여 14 시간에 다 시 감소하였다. 젖산균의 최대 성장시간 이후 에 젖산균의 수가 다소 증감이 있었는데 이는 젖산균의 생장이 2 4시간째 대수성장기를 지 나 RPA 처리구의 경우 배양 4시간 이후 정체 기에 들어감으로써 정체기 이후 젖산균의 생장 이 정지, 사멸 및 생장이 동시에 이루어지면서 좀더 많은 산 생성에 의해 정체기에서 사멸기 로 가는 중에 증감이 있는 것으로 생각되어진 다. 또한 $\mathrm{pH}$ 와 산도는 젖산균 수의 증감과 유 사한 경향을 보이지 않은 것은 배양이 시작되 면서 생성된 산은 발효유내에 존재함으로 젖산 균 수가 감소되더라도 산 생성량은 증가되는 것으로 생각된다.

Collins 등(1991)은 고구마를 첨가하여 요구르 트의 점도를 증가시키고 발효시간을 연장시켰 으나 많은 양을 첨가하면 젖산균의 성장을 저 해하고 첨가하는 정도가 소비자들의 선택에 영 향을 준다고 하였다.

\section{4. 점도}

최적의 기질 함량으로 선정된 쌀 분말과 탈 지분유를 각 $4 \%$ 씩 첨가하여 젖산균주를 달리 하여 제조한 요구르트의 점도는 산도 $1 \%$ 에 도 달하는 시점에 시료를 취하여 분석한 결과는 Table 4와 같다. 백 등(2004)의 결과에서는 쌀 분말과 탈지분유를 $4 \%$ 첨가한 시료의 산도가 $1 \%$ 일 때의 점도는 $1153 \mathrm{cP}, 1833 \mathrm{cP}$ 로 나타났는데 L. salivarius ssp. salivarius균으로 제조한 요구르 트 중 쌀 분말과 탈지분유를 첨가한 시료의 산도 가 $1 \%$ 일 때의 점도는 $400 \mathrm{cP}, 425 \mathrm{cP}$ 로써 다른 젖산균주를 사용한 요구르트에 비해 점도가 매 우 낮았으며 첨가물에 따른 유의차는 나타나지
Table 4. Viscosity of yogurt by various lactic acid bacteria

(unit: $\mathrm{cP}$ )

\begin{tabular}{lc}
\hline Sample* $^{*}$ & Viscosity \\
\hline \hline RP A & $400^{\mathrm{e}}$ \\
RP B & $1,150^{\mathrm{d}}$ \\
RP C & $1,300^{\mathrm{c}}$ \\
SMP A & $425^{\mathrm{e}}$ \\
SMP B & $1,450^{\mathrm{b}}$ \\
SMP C & $1,850^{\mathrm{a}}$ \\
& \\
F-value & 13.34 \\
\hline
\end{tabular}

Values with different letters are significantly different $(\mathrm{p}<0.05)$.

RP : $4 \%$ rice powder, SMP : $4 \%$ skim milk powder.

A : L. salivarius ssp. salivarius.

B : L. casei YA-70.

C : mixed culture(B. longum, L. acidophilus and Streptococcus salivarius ssp. thermophilus).

* Samples is prepared from yogurt that has reached $1.0 \%$ titratable acidity.

않았다. L. casei로 제조한 요구르트와 B. longum, L. acidophilus, Streptococcus salivarius ssp. thermophilus의 혼합 균주로 제조한 요구르 트에서는 탈지분유를 첨가한 시료가 쌀 분말을 첨가한 시료보다 점도가 더 높았으며 시료 간 에 각각 유의차를 나타내었다. 특히 B. longum, L. acidophilus, Streptococcus salivarius ssp. thermophilus의 혼합 균주로 제조한 요구르트에 서는 탈지분유를 $4 \%$ 첨가한 시료가 $1,850 \mathrm{cP}$ 로 모든 시료 중에서 점도가 가장 높았다. 이와 같이 젖산균주에 관계없이 탈지분유를 첨가한 시료가 쌀 분말을 첨가한 시료보다 점도가 모 두 높았는데 이는 요구르트의 점도에는 고형분 의 함량보다 단백질의 함량이 미치는 영향이 더 큰 것으로 생각된다.

김과 고(1993)는 우유와 쌀, 보리, 밀, 옥수수 를 이용한 요구르트 제조에서 점도에 미치는 첨가물의 효과는 대조구에 비하여 탈지분유 첨 가구와 보리를 제외한 곡류 첨가군의 점도가 대체적으로 유의성 있게 높았으며 $(\mathrm{p}<0.05)$, 모 든 시료 가운데 옥수수 첨가 시료의 점도가 가 장 높았다고 보고하였다. 보리 첨가 시료의 점 
도는 대조구 보다도 낮았는데 그 이유는 24시 간 발효한 후 커드 위에 생긴 상층액이 점도 측정 시 커드가 파괴되면서 혼합되어 점도를 감소시켰기 때문이었으며 곡류 첨가구는 전분 으로 인하여 점도가 높았던 것으로 생각되었 다. 김과 고(1990)는 요구르트의 점도에 미치는 젖산균의 효과에서 L. acidophilus로 만든 시료 가 대체적으로 높은 점도를 나타냈고 Leuc. mesenteroides로 만든 시료가 대체적으로 낮은 점도를 나타내었다고 보고하였다.

\section{5. 유기산}

쌀 분말과 탈지분유를 각 $4 \%$ 씩 첨가하고 젖 산균주를 달리하여 요구르트를 제조한 후 산도 가 $1 \%$ 에 도달했을 때의 시료를 취하여 분석한 유기산의 종류와 함량은 Table 5 같다. Table 5 에서 보는 바와 같이 젖산균주를 달리하여 제 조한 요구르트는 상업용 혼합 균주를 사용한 백 등(2004)의 결과에서 보다 lactic acid는 감 소하였으나 acetic acid는 부분적으로 증가하 였다. L. salivarius ssp. salivarius와 B. longum, L. acidophilus, Streptococcus salivarius ssp. thermophilus의 혼합 균주로 제조한 요구르트 중 쌀 분말을 첨가한 시료가 탈지분유를 첨가 한 시료보다 lactic acid가 증가하였으며 L. casei
로 제조한 요구르트 중 탈지분유를 첨가한 시 료의 lactic acid가 증가하였다. 또한 B. longum, L. acidophilus, Streptococcus salivarius ssp. thermophilus의 혼합 균주로 제조한 요구르트 중 탈지분유를 첨가한 시료에서 요구르트의 향 기성분인 acetic acid가 가장 많이 증가하였다. Shin(1989)이 제조한 요구르트에서도 배양 후 12 시간까지 acetic acid가 증가하였다. Isobutyric acid는 탈지분유를 첨가하고 L. salivarius ssp. salivarius를 사용하여 제조한 요구르트에서만 생성되었다. 홍과 고(1991)에 의하면 우유에 탈 지분유 또는 4 종의 쌀(멥쌀, 찹쌀, 현미, 통일 벼)을 각각 $2 \%(\mathrm{w} / \mathrm{v})$ 첨가하여 커드상의 요구르 트를 만들고 대조구(우유로만 만든 요구르트)과 비교하여 쌀의 첨가가 젖산균의 산 생성에 미 치는 영향을 조사하였는데 쌀의 첨가로 젖산균 의 산 생성이 대조구보다 촉진되었으며 현미의 촉진 효과가 가장 현저하였다. 접종된 4종의 젖산균(Lactobacillus 3종, Leuconostoc 1종) 중에 서 L. mesenteroides와 L. delbrueckii ssp. bulgaricus를 접종하여 24시간 발효하는 동안 lactic acid는 젖산균에 의해 생성되어 그 양이 현저하게 증가하였으나 우유 중에 들어있는 citric acid는 젖산균에 의해 이용되어 그 양이 현저하게 감소하였다고 보고하였다. 김과 고 (1993)는 우유와 쌀, 보리, 밀, 옥수수를 이용한

Table 5. Organic acid contents of yogurt by various lactic acid bacteria

(unit : mM)

\begin{tabular}{lcccc}
\hline \multicolumn{1}{c}{ Sample* $^{*}$} & Tartaric acid & Lactic acid & Acetic acid & Isobutyric acid \\
\hline \hline Control : RP 4 & 0.40 & 157.10 & - & 11.59 \\
\multicolumn{1}{c}{ SMP 4 } & 0.38 & 203.32 & - & 17.06 \\
RP A & 7.97 & 93.24 & - & - \\
RP B & 4.96 & 79.80 & - & - \\
RP C & 14.40 & 93.29 & 36.81 & - \\
SMP A & 10.95 & 73.94 & 0.34 & 10.89 \\
SMP B & 10.49 & 102.57 & 0.49 & - \\
SMP C & 18.42 & 87.68 & 43.98 & - \\
\hline
\end{tabular}

RP : $4 \%$ rice powder, SMP : $4 \%$ skim milk powder.

A : L. salivarius ssp. salivarius.

B : L. casei YA-70.

C : mixed culture(B. longum, L. acidophilus and Streptococcus salivarius ssp. thermophilus).

* Samples is prepared from yogurt that has reached $1.0 \%$ titratable acidity. 
요구르트를 제조하였는데 접종된 3종의 젖산균 가운데 산 생성이 우수한 것은 L. acidophilus였 으며 L. casei와 L. delbrueckii ssp. bulgaricus의 산 생성은 저조하였으며 이러한 경향은 대조구 와 탈지분유 첨가구, 곡류 첨가구 어느 경우에 서나 일치하였으며 각각의 젖산균 사이에는 $5 \%$ 수준에서 유의차가 있었다고 보고하였다.

\section{6. 탄수화물}

쌀 분말과 탈지분유를 각 $4 \%$ 씩 첨가하고 젖 산균주를 달리하여 요구르트를 제조한 후 배양 직후(0시간)와 산도가 $1 \%$ 에 도달했을 때의 시 료를 취하여 탄수화물을 분석하였다. Table 6에 서 보는 바와 같이 배양 직후(0시간)에 측정한 lactose 함량을 보면 쌀 분말을 첨가한 시료는 모두 대조구보다 적었으나 이 시료 중에서는 L. salivarius ssp. salivarius로 배양한 시료의 lactose 함량이 가장 많았다. 탈지분유를 첨가한 시료도 모두 대조구보다 lactose 함량이 적었으 나 이 시료 중에서는 B. longum, L. acidophilus, Streptococcus salivarius ssp. thermophilus의 혼합 균주로 배양한 시료의 lactose 함량이 가장 많 았다. 산도가 $1 \%$ 에 도달했을 때의 시료의 유당
가수분해율을 보면 세 가지 젖산균주 모두 쌀 분말을 첨가한 시료가 탈지분유를 첨가한 시료 보다 더 높았다. 그 중에서 L. salivarius ssp. salivarius로 배양한 시료의 가수분해율이 $58.10 \%$ 로 가장 높았다. B. longum, L. acidophilus, Streptococcus salivarius ssp. thermophilus의 혼합 균주를 사용하여 제조한 탈지분유 첨가 요구르 트에서 galactose가 $0.23 \%$ 생성되었으며 이 경 우에도 glucose는 극히 미량 존재하므로 측정할 수 없었다.

\section{7. 관능검사}

쌀 분말과 탈지분유를 각 $4 \%$ 씩 첨가하고 젖 산균주를 달리하여 제조한 요구르트가 배양 후 산도 $1 \%$ 에 도달했을 때의 관능검사 결과는 Table 7과 같다. Table 7에서 보는 바와 같이 색과 풍미, 단맛과 신맛의 조화, 조직감 및 전 체적인 기호도에서 젖산균주에 따라 시료 간에 유의차를 나타내었다. 색과 맛의 경우 쌀 분말 을 첨가한 시료는 젖산균주에 따른 차이를 나 타내지 않았으나 탈지분유를 첨가한 시료 중 B. longum, L. acidophilus, Streptococcus salivarius ssp. thermophilus의 혼합 균주로 제조한 요구르

Table 6. Changes of carbohydrates of yogurt by various lactic acid bacteria

(unit: \%)

\begin{tabular}{lcccc}
\hline \multirow{2}{*}{ Sample } & \multicolumn{3}{c}{ Carbohydrates } \\
\cline { 2 - 4 } & \multicolumn{2}{c}{ Lactose } & Hydrolysis rate of Lactose & Galactose \\
\cline { 2 - 4 } & $0 \mathrm{hr}$ & $\mathrm{TA}^{*} 1.0 \%$ & 20.27 & 0.92 \\
\hline \hline Control : RP 4 & 4.44 & 3.54 & 33.20 & 1.03 \\
SMP 4 & 7.56 & 5.05 & 58.10 & - \\
RP A & 3.38 & 1.42 & 32.00 & - \\
RP B & 3.12 & 2.12 & 41.12 & - \\
RP C & 3.10 & 1.83 & 11.88 & 0.21 \\
SMP A & 5.37 & 4.73 & 13.53 & - \\
SMP B & 5.29 & 4.57 & 25.79 & 0.23 \\
SMP C & 5.76 & 4.27 & &
\end{tabular}

$\mathrm{RP}: 4 \%$ rice powder, SMP : $4 \%$ skim milk powder.

A : L. salivarius ssp. salivarius.

B : L. casei YA-70.

C : mixed culture(B. longum, L. acidophilus and Streptococcus salivarius ssp. thermophilus).

* Samples is prepared from yogurt that has reached $1.0 \%$ titratable acidity. 
Table 7. Sensory evaluation of yogurt by various lactic acid bacteria

\begin{tabular}{lccccc}
\hline Sample* & Color & Flavor & Sweet and sour taste & Texture & Overall acceptability \\
\hline \hline RP A & $3.69 \pm 0.712^{\mathrm{a}}$ & $2.97 \pm 0.823^{\mathrm{b}}$ & $3.45 \pm 1.152^{\mathrm{a}}$ & $2.90 \pm 0.900^{\mathrm{b}}$ & $2.93 \pm 1.222^{\mathrm{b}}$ \\
RP B & $3.51 \pm 0.574^{\mathrm{a}}$ & $2.93 \pm 0.753^{\mathrm{b}}$ & $3.14 \pm 0.789^{\mathrm{a}}$ & $3.28 \pm 0.960^{\mathrm{a}}$ & $2.97 \pm 0.823^{\mathrm{b}}$ \\
RP C & $3.45 \pm 0.631^{\mathrm{a}}$ & $3.38 \pm 0.728^{\mathrm{a}}$ & $3.59 \pm 0.786^{\mathrm{a}}$ & $3.45 \pm 0.985^{\mathrm{a}}$ & $3.52 \pm 0.785^{\mathrm{a}}$ \\
SMP A & $3.24 \pm 0.739^{\mathrm{b}}$ & $2.72 \pm 0.996^{\mathrm{b}}$ & $2.66 \pm 1.140^{\mathrm{b}}$ & $2.72 \pm 0.797^{\mathrm{b}}$ & $2.55 \pm 1.270^{\mathrm{c}}$ \\
SMP B & $3.24 \pm 0.646^{\mathrm{b}}$ & $2.52 \pm 0.738^{\mathrm{c}}$ & $2.45 \pm 0.948^{\mathrm{b}}$ & $2.76 \pm 0.912^{\mathrm{b}}$ & $2.24 \pm 0.988^{\mathrm{c}}$ \\
SMP C & $3.62 \pm 0.676^{\mathrm{a}}$ & $2.90 \pm 0.724^{\mathrm{b}}$ & $3.21 \pm 0.774^{\mathrm{a}}$ & $2.93 \pm 0.842^{\mathrm{b}}$ & $3.03 \pm 0.906^{\mathrm{a}}$ \\
\hline F-value & 2.336 & 3.742 & 6.431 & 3.043 & 5.364 \\
\hline
\end{tabular}

Values with different letters are significantly different $(\mathrm{p}<0.05)$.

RP : $4 \%$ rice powder, SMP : $4 \%$ skim milk powder.

A : L. salivarius ssp. salivarius.

B : L. casei YA-70.

C : mixed culture(B. longum, L. acidophilus and Streptococcus salivarius ssp. thermophilus).

* Samples is prepared from yogurt that has reached $1.0 \%$ titratable acidity.

트가 L. salivarius ssp. salivarius와 L. casei로 제 조한 요구르트와 유의차를 나타내었다. 풍미와 전체적인 기호도의 경우 쌀 분말을 첨가한 시 료 중에서 L. salivarius ssp. salivarius와 L. casei 로 제조한 요구르트는 B. longum, L. acidophilus, Streptococcus salivarius ssp. thermophilus의 혼합 균주로 제조한 요구르트와 유의차를 나타내었다. 탈지분유를 첨가한 시료 중에서는 L. salivarius ssp. salivarius와 B. longum, L. acidophilus, Streptococcus salivarius ssp. thermophilus의 혼합 균주로 제조한 요구르트가 L. casei로 제조한 요구르트와 유의차를 나타내었다. 조직감의 경 우 탈지분유를 첨가한 시료는 젖산균주에 따른 차이를 나타내지 않았으나 쌀 분말을 첨가한 시료 중에서 L. salivarius ssp. salivarius로 제조한 요구르트가 L. casei와 B. longum, L. acidophilus, Streptococcus salivarius ssp. thermophilus의 혼합 균 주로 제조한 요구르트와 유의차를 나타내었다.

김 등(1993)은 팽화미를 첨가한 요구르트의 제조에서 관능검사의 결과를 보면 팽화미분을 $4 \%$ 첨가했을 때까지는 색택, 풍미, 맛 및 전체 적인 기호도에서 유의적인 차이가 없었으나 팽 화미분의 첨가량이 증가할수록 색택, 풍미, 조 직감 및 맛이 떨어지는 현상을 보였으며 특히 꺼끌꺼끌한 촉감이 나타났다고 보고하였다. Shin (1989)의 보고에 의하면 멥쌀을 12 시간 침지하였 다가 $121^{\circ} \mathrm{C}$ 에서 20 분간 살균한 후 a-amylase를
작용시켜 액화시킨 후 이 액에 L. delbrueckii ssp. bulgaricus와 Streptococcus salivarius ssp. thermophilus, L. plantarum을 단독으로 또는 혼 합하여 접종한 후 발효시켰는데 24시간 이후 젖산균의 산 생성은 세 균주를 동시 접종한 경 우가 가장 높았다. 관능검사의 결과를 보면 $\mathrm{pH} 3.7$ 부근의 시료 또는 세 균주를 혼합 배 양하여 제조한 시료의 관능성이 가장 우수하 였다. 목 등(1991)은 호화시킨 쌀을 당화시킨 후 L. delbrueckii ssp. bulgaricus와 Streptococcus salivarius ssp. thermophilus, L. plantarum을 단독으 로 또는 Streptococcus salivarius ssp. thermophilus 와 혼합 배양하였는데 L. delbrueckii ssp. bulgaricus와 Streptococcus salivarius ssp. thermophilus를 1:1로 혼합 배양하여 만든 제품 의 기호도가 가장 높았으며 배양시 a-amylase와 amyloglucosidase를 각각 $0.02 \%$ 수준으로 2차 당화와 발효를 동시에 진행한 경우 신맛과 단 맛이 증가하였고 불용성 고형물 입자의 크기가 감소하여 기호도가 뚜렷하게 향상되었다고 보 고하였다.

\section{IV 요 약}

본 연구는 탈지유에 $4 \%$ 의 쌀 분말과 탈지 분유를 첨가하여 단독 균주인 L. salivarius ssp. salivarius와 L. casei 그리고 B. longum, L. 
acidophilus, Streptococcus salivarius ssp. thermophilus의 혼합 균주로 요구르트를 제조하여 젖 산균주에 따른 발효특성을 연구하였다.

L. salivarius ssp. salivarius로 제조한 요구르 트의 경우 쌀 분말과 탈지분유를 첨가한 시료 모두 산 생성이 활발하지 못해 배양 14 시간까 지 적정 $\mathrm{pH}$ 인 4.5 와 적정 산도인 $1.0 \%$ 에 도달 하지 못하였다. L. casei로 제조한 요구르트의 경우 발효는 빨리 진행되었으나 8시간 이후부터 는 $\mathrm{pH}$ 와 산도가 너무 낮아 요구르트의 품질을 유지하기가 어려웠다. B. longum, L. acidophilus, Streptococcus salivarius ssp. thermophilus의 혼합 균주로 제조한 요구르트 중 탈지분유를 첨가한 시료는 배양 8 시간 이후부터 14 시간까지 적정 $\mathrm{pH}$ 와 산도가 잘 유지되었다. 점도는 균주의 종 류에 관계없이 탈지분유를 첨가한 시료가 쌀 분말을 첨가한 시료보다 높았다.

L. salivarius ssp. salivarius와 B. longum, $L$. acidophilus, Streptococcus salivarius ssp. thermophilus의 혼합 균주로 제조한 요구르트 중에 서는 쌀 분말을 첨가한 시료가, 그리고 L. casei 로 제조한 요구르트 중에서는 탈지분유를 첨가 한 시료가 lactic acid의 생성량이 많았다. B. longum, L. acidophilus, Streptococcus salivarius ssp. thermophilus의 혼합 균주로 제조한 요구르 트에서는 쌀 분말과 탈지분유를 첨가한 시료에 서 요구르트의 향기성분인 acetic acid가 많이 생 성되었다. Galactose는 B. longum, L. acidophilus, Streptococcus salivarius ssp. thermophilus의 혼합 균주와 L. salivarius ssp. salivarius로 제조한 요 구르트에서 측정되었다. 관능검사 결과 쌀 분 말을 첨가한 시료가 모든 항목에서 높은 값을 나 타내었으며 젖산균주에 따른 차이를 보면 색은 L. salivarius ssp. salivarius가 가장 높은 값을 나 타내었으나 풍미와 단맛과 신맛의 조화, 조직감, 전체적인 기호도에서는 B. longum, L. acidophilus, Streptococcus salivarius ssp. thermophilus의 혼합 균주가 가장 높은 값을 나타내었다. 이러한 결 과를 바탕으로 $4 \%$ 쌀 첨가 요구르트의 제조에 사용되는 젖산균주는 B. longum, L. acidophilus, Streptococcus salivarius ssp. thermophilus의 혼합 균주가 가장 좋은 것으로 판단된다.

\section{$\mathrm{V}$ 인 용 문 헌}

1. Collins, J. L., Ebah., C. B., Mount., J. R., B. Demott, B. J. and Draughon. F. A. 1991. Production and evaluation of milk sweet potato mixtures fermented with yogurt bacteria. J. Food Sci. 56:685-688.

2. Jeon, F. M., Galitzer, S. J. and Hennessy, K. J. 1984. Rapid determination of lactose and its hydrolysates in whey and whey permeate by high performance liquid chromatography. J. Dairy Sci. 67:884-887.

3. Saidi, B. and Warthesen, J. J. 1989. Analysis and stability of orotic acid in milk. J. dairy Sci. 72: 2900-2905.

4. Shin. D. H. 1989. A yogurt like product development from rice by lactic acid bacteria. Korean J. Food Sci. Technol. 21:686-690.

5. Tamine, A. Y. and Robinson, R. K. Yogurt: 1985. Science and Technology. Pergamon Press Ltd. England.

6. Yu, T. J. and Lee. J. W. 1982. Studies on preparation of lactic acid fermentation beverage from a malt syrup. Korean J. Food Sci. Technol. 14:57-62.

7. 김경희, 고영태. 1993. 우유와 곡류를 이용한 요 구르트의 제조. 한국식품과학회지. 25:130-135.

8. 김문, 안은숙, 신동화. 1993 . 팽화미의 첨가가 요 구르트 특성에 미치는 영향. 한국식품과학회지. 25:258-263.

9. 김혜정, 고영태. 1990. 우유와 대두단백질을 이용 한 요구르트의 제조에 관한 연구. 한국식품과학 회지. 22:700-706.

10. 목철균, 남영중, 김영진, 김남수, 권대영. 1991. 쌀의 젖산발효 중 전분가수분해 효소 처리에 의 한 품질향상. 한국식품과학회지. 23:739-744.

11. 배형철. 2002. 한국인 분변으로부터 Lactobacillus ssp. 의 분리 및 probiotic 특성. 충남대학교 박사학 위논문.

12. 백승희, 배형철, 남명수. 2004. 쌀 분말 첨가량에 따른 요구르트의 발효 특성. 한국동물자원과학회 지. 46:667-676.

13. 식품공전. 1994. 한국식품공업협회. 서울.

14. 안효일, 김형기, 이성갑, 양철형, 양종범, 윤원호. 1988. 식품가공학. 세진사. 서울.

15. 이신구. 1983. 우유 및 유제품 검사. 선진문화사. 서울.

16. 이철호, 무사수안네, 류기형. 1988. 예비발효 및 압출조리 전처리가 쌀 - 대두분 혼합액의 유산균 발효에 미치는 영향. 한국식품과학회지. 20:666-673.

17. 홍외숙, 고영태. 1991. 우유와 쌀을 이용한 요구르 트의 제조에 관한 연구. 한국식품과학회지. 23: 587-592.

(접수일자 : 2004. 5. 31. / 채택일자 : 2004. 8. 4.) 